\title{
PENGGUNAAN METODE PROFILE MATCHING DALAM SISTEM PENDUKUNG KEPUTUSAN KENAIKAN JABATAN PADA INSTITUSI BANK (STUDI KASUS PT Bank Negara Indonesia, Persero Tbk - KC PECENONGAN)
}

\author{
Arfhan Prasetyo ${ }^{1}$ \\ Program Studi Sistem Informasi \\ Akuntansi, Universitas Bina Sarana \\ Informatika Jl. Kamal Raya No. 18 \\ Jakarta Barat Indonesia E-mail : \\ arfhan.afp@bsi.ac.id
}

\author{
Ani Oktarini Sari ${ }^{2}$ \\ Program Studi Sistem Informasi, \\ Universitas Bina Sarana \\ Informatika, Jl. Kamal Raya No. 18 \\ Jakarta Barat Indonesia E-mail : \\ ani.aos@bsi.ac.id
}

\author{
Rizky Aprilia ${ }^{3}$ \\ Program Studi Sistem Informasi, \\ STMIK Nusa Mandiri, Jl Kramat \\ Raya No.18 Jakarta Pusat Indonesia \\ E-mail : \\ 11170842@nusamandiri.ac.id
}

\begin{abstract}
ABSTRAK
Sering kali pemilihan kandidat karyawan yang akan di promosikan untuk jabatan tertentu pada suatu perusahaan sebetulnya tidak cocok untuk mengisi jabatan tersebut, karena sebelumnya tidak ditentukan terlebih dahulu GAP antara kompetensi individu dan kompetensi jabatan yang dapat mengarahkan karyawan ke jabatan yang sesuai dengan kompetensi dasar yang dimiliki. Penelitian ini bertujuan untuk membantu PT Bank Negara Indonesia (Persero), Tbk KCU Pecenongan dalam proses seleksi promosi jabatan dari kandidat Costumer Service Officer (CSO) untuk menempati posisi jabatan Personal banking Officer (PBO) dengan menggunakan metode Profile Matching. Metode ini dilakukan dengan tahapan, menentukan aspek dan sub aspek penilaian, menentukan nilai target dari masing-masing sub aspek, menentukan GAP kompetensi dari selisih antara nilai aspek dan nilai target, melakukan pembobotan nilai GAP, mengkelompokan aspek menjadi 2 kelompok yaitu core factor dan secondary factor, melakukan perhitungan nilai total berdasarkan presentasi dari core factor dan secondary factor, hasil akhir setelah melakukan penilaian dengan metode profile matching pada sistem promosi jabatan dengan cara memilih kandidat dari costumer service officer (CSO) PT Bank Negara Indonesia (Persero), Tbk Kantor Cabang Utama Pecenongan untuk menempati posisi jabatan Personal Banking Officer (PBO) terlihat perbedaan nilai yang lebih baik dari perhitungan sebelumnya yang masih dilakukan dengan sederhana tanpa ada pemberian nilai target, pemetaan nilai bobot GAP dan nilai factor yakni Core Factor dan Secondary Factor yang dilanjutkan dengan hitung rangking.
\end{abstract}

\begin{abstract}
Job Ascension Decision Support System Using Profile Matching Method Case Study at PT Bank Negara Indonesia (Persero), Tbk KCU Pecenongan. Often the selection of employee candidates to be promoted for certain positions in a company is actually not suitable to fill these positions, because previously there was no prior GAP determination between individual competencies and job competencies that could direct employees to positions that were in accordance with their basic competencies. This study aims to assist PT Bank Negara Indonesia (Persero), Tbk KCU Pecenongan in the selection process of promotion from Costumer Service Officer (CSO) candidates to occupy the position of Personal Banking Officer (PBO) using the Profile Matching method. This method is carried out by stages, determining aspects and sub aspects of the assessment, determining the target value of each subaspect, determining the GAP competence from the difference between the aspect value and target value, weighting the GAP value, grouping aspects into 2 groups, namely core factor and secondary factor, calculating the total value based on the presentation of core factor and secondary factor, the final result after evaluating the profile matching method in the promotion system by selecting candidates from customer service officers (CSO) PT Bank Negara Indonesia (Persero), Tbk Branch Offices Utama Pecenongan to occupy the position of Personal Banking Officer (PBO) shows a difference in values that are better than the previous calculations that are still done simply without giving the target value, mapping the GAP weighting value and the factor value, namely Core Factor and Secondary Factor, followed by calculating rank.
\end{abstract}


Key Word: Decision Support System, Profile

\section{PENDAHULUAN}

Perusahaan merupakan suatu organisasi yang harus berproduksi, dimana manusia berfungsi sebagai tenaga penggerak dan pelaksana untuk mewujudkan tujuan perusahaan yang telah ditetapkan sebelumnya. Suatu perusahaan tidak terlepas dari peranan Sumber Daya Manusia (SDM) yang bekerja di dalamnya (Handayani, 2017). Dalam sebuah perusahaan memiliki elemen penting yaitu Sumber Daya Manusia (SDM). Pengelolaan SDM dipimpin oleh General Manager yang mempunyai fungsi merencanakan, mengorganisasikan, menyelenggarakan, melakukan pengawasan, monitoring dan evaluasi atas seluruh kegiatan pengelolaan SDM. Pengelolaan SDM sangat mempengaruhi banyak aspek penentu. Jika SDM dikelola dengan baik, maka diharapkan perusahaan dapat menjalankan usahanya dengan baik. Setiap karyawan di sebuah perusahaan tentunya selalu berusaha meningkatkan kemampuan dan prestasinya. Sehingga dia bisa mendapatkan jenjang karir yang bagus sesuai idamannya. Kemampuan yang handal akan menunjang perkembangan perusahaan tentunya akan membuat seseorang mudah mendapatkan promosi kenaikan jabatan yang lebih tinggi dari posisi sebelumnya. Kenaikan jabatan juga diberikan perusahaan dalam rangka memberikan penghargaan atas prestasi tertentu.

Sistem kompetensi merupakan salah satu pemecahan masalah bagi aset SDM dan terdapat pendeskripsian prestasi dan potensi SDM sesuai unit kerjanya. Pencapaian prestasi karyawan dan potensinya dapat terlihat apakah kompetensinya tersebut telah sesuai dengan tugas pekerjaan yang dimilikinya. Menurut (Hidayat, 2013) jabatan kosong pada proses kenaikan jabatan sering mengalami kesulitan karena pengajuan calon kandidat yang bisa menempati jabatan tersebut dengan cara pencocokan profil karyawan dan profil jabatan kurang terdefinisi dengan baik. Untuk meminimumkan kendala tersebut diperlukan suatu sistem pendukung keputusan yang dapat menganalisa beberapa karyawan yang sesuai dengan profil jabatan yang ada. Sumber daya Manusia (SDM) adalah salah satu elemen dalam perusahaan yang cukup penting dalam hal pembinaan dan pengembangan para

\section{Matching, GAP, Position}

karyawan, oleh karena itu peran SDM dari suatu perusahaan sangat mempengaruhi beberapa aspek penentu keberhasilan kerja dari perusahaan tersebut. Jika SDM dapat diorganisir dengan baik, maka diharapkan perusahaan dapat menjalankan semua proses usahanya dengan baik.Tujuan dari penelitian ini untuk : Membuat sistem pendukung keputusan yang dapat membantu menentukan pengambilan keputusan dalam promosi jabatan dari unit Customer Service ke jabatan Personal Banking Officer di PT Bank Negara Indonesia (Persero), Tbk Kantor Cabang Utama Pecenongan. Mempercepat tingkat keakuratan dan proses seleksi yang relevan dalam promosi jabatan karyawan dengan menggunakan metode Profile Matching.

\section{METODE PENELITIAN}

\section{A. Tahapan Penelitian}

Menurut (Sugiyono, 2016) Metode penelitian pada dasarnya merupakan cara ilmiah untuk mendapatkan data dengan tujuan dan kegunaan tertentu. Riset atau penelitian sering dideskripsikan sebagai suatu proses investigasi yang dilakukan dengan terencana, teratur dan sistematis yang bertujuan untuk menemukan, menginterpretasikan, serta merevisi fakta-fakta. Sesuai dengan deskripsi tersebutbahwa kegiatan penelitian dilakukan dengan terencana, teratur dan sistematis. Di bawah ini tahapan-tahapan dalam penelitian kenaikan jabatan :

1. Survey Literatur

Dalam tahap awal ini peneliti melakukan pengumpulan berupa bahan literature dan informasi terkait.

2. Identifikasi Masalah

Melanjutkan penelitian dengan cara melakukan identifikasi tentang masalah yang akan dibahas, berkaitan dengan sistem pendukung keputusan kenaikan jabatan menggunakan Metode Profile Matching pada Bank BNI KCU Pecenongan berdasarkan literature dan informasi yang diperoleh. 
3. Studi Pustaka

Peneliti mempelajari literature berupa bukubuku teori tentang sistem pendukung keputusan dan metode Profile Matching yang akan digunakan sebagai kajian teori dalam penelitian.

4. Hipotesis
a.) Tidak adanya perbedaan penilaian dalam promosi jabatan CSO untuk jabatan PBO antara sistem manual dengan menggunakan metode profile matching.

b.) Adanya perbedaan penilaian dalam promosi jabatan CSO untuk jabatan PBO antara sistem manual dengan menggunakan metode profile matching

5. Menentukan Kriteria dan Sumber Data

Peneliti menentukan kriteria dari sistem pendukung keputusan kenaikan jabatan menggunakan metode Profile Matching pada PT Bank Negara Indonesia (Persero), Tbk Kantor Cabang Utama Pecenongan dari aspek kinerja dan aspek sikap kerja. Kemudian menentukan data-data seperti apa yang dibutuhkan berdasarkan populasi, sampel dan cara pengambilan sampel yang di dapat dari wawancara dengan bagian administrasi umum dan pemimpin cabang.

6. Mengumpulkan Data

Pada tahap ini, dilakukan dengan cara observasi dan wawancara dengan kepala cabang utama serta dengan pengumpulan dokumen-dokumen yang dapat dijadikan sebagai sumber penelitian.

7. Perhitungan Manual Berjalan

Dalam tahap ini, perhitungan masih dilakukan secara manual dimana nilai rating dan bobot dikalikan dan di jumlahkan tanpa menentukan pemetaan GAP Kompetensi, Bobot Nilai, Core Factor \& Secondary Factor dan Nilai Total seperti pada Metode Profile Matching.

8. Perhitungan Dengan Metode Profile Matching Dalam tahap ini, data dari aspek kinerja dan aspek Pelayanan akan dianalisis, analisa data dilakukan dengan menggunakan metode Profile Matching. Metode Profile Matching termasuk ke dalam penelitian kuantitatif yang bersifat deskriptif dimana metode Profile Matching ini akan menghitung angka-angka yang ada pada data dari aspek kinerja dan aspek sikap kerja karyawan PT Bank Negara Indonesia (Persero), Tbk Kantor Cabang Utama Pecenongan.

9. Menarik Kesimpulan

Peneliti menarik sebuah kesimpulan berdasarkan perhitungan data pada bab-bab sebelumnya dan diperiksa apakah kesimpulan sesuai dengan hipotesis, maksud dan tujuan penelitian. Selain itu memberikan saran yang dapat digunakan sebagai masukan bagi perusahaan terkait untuk dimanfaatkan lebih lanjut.

\section{B. Instrument Penelitian}

Instrumen penelitian disebut juga sebagai alat bantu untuk mengumpulkan data dalam melakukan penelitian. Instrumen-instrumen penelitian yang dibutuhkan dalam melakukan penelitian ini adalah :

1. Instrumen Pokok

a. Narasumber

b. Penulis atau Peneliti

2. Instrumen Pendukung

a. Pedoman Wawancara

\section{Metode Pengumpulan Data, Populasi dan Sample Penelitian}

Teknik pengumpulan data menurut (Ariwisanto Sianturi, 2015) pengumpulan data dilakukan bertujuan untuk memperoleh data-data yang terkait dengan sistem pendukung keputusan untuk kenaikan jabatan. Tahap-tahap yang dilakukan dalam pengumpulan data ialah studi pustaka, studi lapangan dan studi literatur.

\section{a. Populasi}

Menurut (Sugiyono, 2016) Populasi adalah wilayah generalisasi yang terdiri atas: obyek/subyek yang mempunyai kualitas dan karakteristik tertentu yang ditetapkan oleh peneliti untuk dipelajari dan kemudian ditarik kesimpulannya. Populasi dalam penelitian ini yaitu CSO yang ada di Bank BNI KCU Pecenongan yang akan di promosikan naik jabatan.

\section{b. Sampel}

Sedangkan sampel menurut (Sugiyono, 2016) Sampel adalah bagian dari jumlah dan karakteristik yang dimiliki oleh 
populasi tersebut. Bila populasi besar, dan peneliti tidak mungkin mempelajari semua yang ada pada populasi, misalnya karena keterbatasan tenaga dan waktu, maka peneliti dapat menggunakan sampel yang diambil dari populasi itu. Menurut (Kristiana, 2015) pemilihan sampel dilakukan berdasarkan tujuan dari penelitian dan pertimbangan-pertimbangan tertentu. Penulis mengambil 10 customer Service untuk dijadikan sampel dari 22 populasi cso yang ada dalam penelitian ini.

\section{Metode Analisa Data}

Untuk mencapai tujuan dari penelitian ini, maka metode analisis data yang digunakan adalah metode kuantitatif. Metode kuantitatif biasa dinamakan dengan metode tradisional, karena metode ini sudah cukup lama digunakan sehingga sudah mentradisi sebagai metode untuk penelitian. Metode profile matching ini digunakan sebagai metode penelitian ilmiah karena telah memenuhi kaidah-kaidah ilmiah yaitu konkrit, obyektif, terukur, rasional, dan sistematis. Metode ini disebut kuantitatif karena data penelitian berupa angka-angka. Tahapan dan perumusan perhitungan dengan metode profile matching adalah sebagai berikut:

1. Menentukan aspek dan sub aspek penilaian

2. Menentukan nilai target dari masing-masing sub aspek

3. Menentukan GAP kompetensi dari selisih antara nilai aspek dan nilai target

4. Melakukan pembobotan nilai GAP

5. Mengkelompokan aspek menjadi 2 kelompok yaitu core factor dan secondary factor

6. Melakukan perhitungan nilai total berdasarkan presentasi dari core factor dan secondary factor

7. Hasil akhir yaitu perhitungan penentuan ranking dari kandidat yang diajukan, semakin besar nilai pada hasil akhir maka semakin besar pula kesempatan menduduki jabatan yang ada demikian sebaliknya.

\section{HASIL DAN PEMBAHASAN}

Setelah melakukan penelitian di PT. Bank Negara Indonesia (Persero), Tbk Kantor Cabang Utama Pecenongan maka akan dilakukan pengujian penilaian dalam menentukan promosi jabatan, dengan menggunakan metode Profile Matching tedapat beberapa aspek yang dinilai dan dari aspek tersebut terdapat sub kriteria, yaitu sebagai berikut :

\section{A. Kriteria Dalam Penentuan Kenaikan Jabatan}

\section{Aspek Kinerja}

a. Aktivasi E-Chanel

Realisasi persentase atau jumlah nasabah baru BNI di area kerja cabang yang mengaktifkan produk e-chanel (diluar ATM) serta melakukan experience dengan menggunakan produk-produk tersebut.

b. Skor PKL - Aspek Customer Service Hasil penilaian kualitas pelayanan customer service terhadap nasabah dari audit external MRI (Marketing Research Indonesia) dan Audit Internal SQU (Service Quality Unit)

c. Closing atas Cross Selling Produk Funding \& Lending

Jumlah referral produk perbankan dan persentase success rate atau closing atas referral dan cross selling produk funding $\&$ lending

d. Referral Bancassurance

Jumlah referral bancassurance kepada product specialist dan persentase success rate atau closing atas referral dan cross selling bancassurance kepada product specialist.

\section{Aspek Sikap Kerja}


a. Profesionalisme

Bekerja secara kontinue untuk menyelesaikan pekerjaannya. Menggunakan kebijakan, prosedur dan pedoman untuk menyelesaikan pekerjaannya. Menyelesaikan pekerjaan sendiri secara efektif dan efisien. Teratur dalam menjalankan pekerjaan rutin, standar dan berkualitas.

b. Integritas

Selalu memberikan informasi yang akurat dan dapat di percaya. Berusaha memahami dan menjalankan peraturan yang berlaku di bawah pengawasan atasan.

\section{c. Orientasi Pelanggan}

Bersungguh-sungguh dalam mendengarkan pelanggannya. Memahami standar dan tindak lanjut layanan pelanggan. Aktif mendukung proses pengambilan keputusan Bersama pihak lain. Bersikap positif dan efektif dalam interaksi dengan pihak lain.

\section{d. Perbaikan Tiada Henti}

Menggali cara baru dalam menyelesaikan pekerjaan. Terlibat dalam pengembangan prosedur baru dengan bimbingan atasan. Menggunakan berbagai sumber alternatife dalam pemecahan masalah. Senantiasa memperbaiki cara kerjanya untuk meningkatkan kinerja.

\section{B. Perhitungan Manual Berjalan}

Berdasarkan hasil wawancara, perhitungan yang saat ini berjalan di Bank BNI KCU Pecenongan masih dilakukan secara manual dimana nilai rating dan bobot dikalikan dan di jumlahkan tanpa menentukan pemetaan GAP Kompetensi, Bobot Nilai, Core Factor \& Secondary Factor dan Nilai Total seperti pada Metode Profile Matching. Berikut hasil perhitungan manual berjalannya :

Tabel 1. Hasil Perhitungan Manual

\begin{tabular}{|c|c|c|c|}
\hline \multicolumn{4}{|c|}{ Hasil Akhir Proses Manual } \\
\hline No & NIK & Skor & Ranking \\
\hline 1 & P030976 & 327.00 & 9 \\
\hline
\end{tabular}

\begin{tabular}{|c|c|c|c|}
\hline 2 & P031866 & 347.00 & 6 \\
\hline 3 & P032402 & 282.00 & 10 \\
\hline 4 & P038036 & 370.00 & 4 \\
\hline 5 & P040507 & 360.00 & 5 \\
\hline 6 & P043560 & 380.00 & 3 \\
\hline 7 & P044012 & 344.00 & 7 \\
\hline 8 & P044410 & 331.00 & 8 \\
\hline 9 & P044961 & 406.00 & 1 \\
\hline 10 & P045080 & 383.00 & 2 \\
\hline
\end{tabular}

\section{Perhitungan Dengan Menggunakan Metode Profile Matching \\ Dengan menggunakan metode Profile Matching} karyawan diukur menggunakan beberapa kriteria penilaian dan beberapa tahapan, berikut ini adalah tahapan-tahapan dari metode profile matching :

\section{Sub Aspek Penilian \\ Nilai Aspek Kinerja}

Tabel 2. Nilai Aspek Kinerja

\begin{tabular}{|c|c|c|c|c|c|}
\hline \multirow{2}{*}{ No } & \multirow{2}{*}{ NIK } & \multicolumn{5}{|c|}{ Nilai Aspek Kinerja } \\
\cline { 3 - 6 } & & KN01 & KN02 & KN03 & KN04 \\
\hline 1 & P030976 & 4 & 3 & 3 & 4 \\
\hline 2 & P031866 & 4 & 3 & 3 & 4 \\
\hline 3 & P032402 & 2 & 3 & 3 & 3 \\
\hline 4 & P038036 & 3 & 3 & 4 & 3 \\
\hline 5 & P040507 & 3 & 3 & 3 & 3 \\
\hline 6 & P043560 & 3 & 4 & 3 & 3 \\
\hline
\end{tabular}




\begin{tabular}{|c|c|c|c|c|c|}
\hline 7 & $\mathrm{P} 044012$ & 2 & 4 & 4 & 4 \\
\hline 8 & $\mathrm{P} 044410$ & 3 & 4 & 3 & 3 \\
\hline 9 & $\mathrm{P} 044961$ & 5 & 3 & 4 & 5 \\
\hline 10 & P045080 & 3 & 4 & 4 & 3 \\
\hline
\end{tabular}

Keterangan :

KN01 : Aktivasi E-Chanel

KN02 : Skor PKL - Aspek Customer Service

KN03 : Closing atas Cross Selling Produk Funding

$\&$

Lending

KN04 : Referral Bancassurance

a. Nilai Aspek Sikap Kerja

Tabel 3. Nilai Aspek Sikap Kerja

\begin{tabular}{|c|c|c|c|c|c|}
\hline \multirow{2}{*}{ No } & \multirow{2}{*}{ NIK } & \multicolumn{4}{|c|}{ Nilai Aspek Sikap Kerja } \\
\cline { 3 - 6 } & & SK01 & SK02 & SK03 & SK04 \\
\hline 1 & P030976 & 3 & 3 & 3 & 3 \\
\hline 2 & P031866 & 4 & 4 & 3 & 3 \\
\hline 3 & P032402 & 3 & 3 & 3 & 3 \\
\hline 4 & P038036 & 3 & 3 & 4 & 3 \\
\hline 5 & P040507 & 3 & 3 & 3 & 3 \\
\hline 6 & P043560 & 3 & 4 & 3 & 4 \\
\hline 7 & P044012 & 4 & 3 & 4 & 3 \\
\hline 8 & P044410 & 4 & 3 & 3 & 3 \\
\hline 9 & P044961 & 4 & 4 & 4 & 4 \\
\hline 10 & P045080 & 4 & 4 & 3 & 3 \\
\hline
\end{tabular}

\section{Keterangan :}

SK01 : Profesionalisme

SK02 : Integritas

SK03 : Orientasi Pelanggan

SK04 : Perbaikan Tiada Henti

\section{Penentuan Nilai Target}

Nilai target ditetapkan berdasarkan standar yang di inginkan oleh perusahaan.
1.) Nilai Target Aspek Kinerja

a.) Aktivasi $E$-Chanel $=3$

b.) Skor PKL - Aspek Customer Service = 4

c.) Closing atas Cross Selling Produk Funding \&

$$
\text { Lending }=5
$$

d.) Referral Bancassurance $=5$

2.) Aspek Sikap Kerja
a.) Profesionalisme $=4$
b.) Integritas $=4$
c.) Orientasi Pelanggan $=4$
d.) Perbaikan Tiada Henti $=4$

\section{Pencarian Nilai GAP}

Untuk mencari nilai gap, dengan menggunakan rumus :

\section{Gap $=$ Profil Karyawan - Profil Jabatan}

\section{Keterangan :}

Profil Karyawan = Nilai perolehan karyawan berdasarkan nilai atasan

Profil Jabatan = Nilai standar yang di tetapkan oleh perusahaan

\section{Tabel 4. Nilai GAP}

\begin{tabular}{|c|c|c|c|c|c|c|c|c|c|}
\hline \multirow{2}{*}{ No } & \multirow{2}{*}{ NIK } & \multicolumn{8}{|c|}{ Profile Karyawan } \\
\hline & & KXO1 & $\mathrm{KNO2}$ & kvas & KNo4 & sko1 & SKO2 & SKa3 & SKOA \\
\hline 1 & P030976 & 4 & 3 & 3 & 4 & 3 & 3 & 3 & 3 \\
\hline 2 & P031866 & 4 & 3 & 3 & 4 & 4 & 4 & 3 & 3 \\
\hline 3 & P032402 & 2 & 3 & 3 & 3 & 3 & 3 & 3 & 3 \\
\hline 4 & P038036 & 3 & 3 & 4 & 3 & 3 & 3. & 4 & 3. \\
\hline 5 & P040507 & 3 & 3 & 3 & 3 & 3 & 3 & 3 & 3 \\
\hline 6 & P043560 & 3 & 4 & 3 & 3 & 3 & 4 & 3 & 4 \\
\hline 7 & p044012 & 2 & 4 & 4 & 4 & 4 & 3 & 4 & 3 \\
\hline 8 & P044410 & 3 & 4 & 3 & 3 & 4 & 3 & 3 & 3 \\
\hline 9 & $\mathrm{PO} 44961$ & 5 & 3 & 4 & 5 & 4 & 4 & 4 & 4 \\
\hline 10 & P045080 & 3 & 4 & 4 & 3 & 4 & 4 & 3 & 3 \\
\hline \multicolumn{2}{|c|}{$\begin{array}{l}\text { Profil } \\
\text { Iabatan }\end{array}$} & 3 & 3 & 4 & 5 & 5 & 4 & 4 & 4 \\
\hline 1 & P030976 & 1 & -1 & -2 & -1 & -1 & -1 & -1 & -1 \\
\hline 2 & P031866. & 1 & -1 & -2 & -1 & 1 & 1 & 0 & 0 \\
\hline 3 & $P 032402$ & -1 & -1 & -2 & -2 & -1 & -1 & -1 & -1 \\
\hline 4 & P038036 & 0 & -1 & -1 & -2 & -1 & -1 & 0 & -1 \\
\hline 5 & P040507 & 0 & -1 & -2 & -2 & -1 & -1 & -1 & -1 \\
\hline 6 & P043560 & 0 & D & -2 & -2 & -1 & 0 & -1 & 0 \\
\hline 7 & $\mathrm{P} 044012$ & -1 & 0 & -1 & -1 & 0 & -1 & 0 & -1 \\
\hline 8 & P044410 & 0 & 0 & -2 & -2 & 0 & -1 & -1 & -1 \\
\hline 9 & P044961 & 2 & -1 & -1 & 0 & 0 & 0 & 0 & 0 \\
\hline 10 & P0430s0 & $D$ & 0 & -1 & -2 & 0 & 0 & -1 & -1 \\
\hline
\end{tabular}

\section{Penentuan Bobot Nilai GAP}

Pembobotan dilakukan setelah diperoleh nilai gap pada masing-masing karyawan, setiap 
profil karyawan diberi bobot nilai sesuai ketentuan pada tabel bobot nilai gap di bawah ini

Tabel 5. Bobot Nilai Gap

\begin{tabular}{|c|c|c|l|}
\hline No & Selisih & Nilai & \multicolumn{1}{|c|}{ Keterangan } \\
\hline 1. & 0 & 5 & Kompetensi sesuai dengan yang dibutuhkan \\
\hline 2. & 1 & 4,5 & Kompetensi individu kelebihan 1 tingkat/level \\
\hline 3. & -1 & 4 & Kompetensi individu kekurangan 1 tingkat/level \\
\hline 4. & 2 & 3,5 & Kompetensi individu kelebihan 2 tingkat/level \\
\hline 5. & -2 & 3 & Kompetensi individu kekurangan 2 tingkat/level \\
\hline 6. & 3 & 2,5 & Kompetensi individu kelebihan 3 tingkat/level \\
\hline 7. & -3 & 2 & Kompetensi individu kekurangan 3 tingkat/level \\
\hline 8. & 4 & 1,5 & Kompetensi individu kelebihan 4 tingkat/level \\
\hline 9. & -4 & 1 & Kompetensi individu kekurangan 4 tingkat/level \\
\hline
\end{tabular}

Tabel 6. Konversi Nilai Bobot

\begin{tabular}{|c|c|c|c|c|c|c|c|c|c|}
\hline \multirow{2}{*}{ No } & \multirow{2}{*}{ NIK } & \multicolumn{7}{|c|}{ Nilai GAP } \\
\cline { 3 - 10 } & & KN01 & SK01 & SK02 & SK03 & SK04 & KN02 & KN03 & KN04 \\
\hline 1 & P030976 & 1 & -1 & -1 & -1 & -1 & -1 & -2 & -1 \\
\hline 2 & P031866 & 1 & 0 & 0 & -1 & -1 & -1 & -2 & -1 \\
\hline 3 & P032402 & -1 & -1 & -1 & -1 & -1 & -1 & -2 & -2 \\
\hline 4 & P038036 & 0 & -1 & -1 & 0 & -1 & -1 & -1 & -2 \\
\hline 5 & P040507 & 0 & -1 & -1 & -1 & -1 & -1 & -2 & -2 \\
\hline 6 & P043560 & 0 & -1 & 0 & 0 & 0 & 0 & -2 & -2 \\
\hline 7 & P044012 & -1 & 0 & -1 & -1 & -1 & 0 & -1 & -1 \\
\hline 8 & P044410 & 0 & 0 & -1 & -1 & -1 & 0 & -2 & -2 \\
\hline 9 & P044961 & 2 & 0 & 0 & 0 & 0 & -1 & -1 & 0 \\
\hline 10 & P045080 & 0 & 0 & 0 & -1 & -1 & 0 & -1 & -2 \\
\hline \multicolumn{7}{|c|}{ Hasil Konversi Nilai B0bot } & & & \\
\hline 1 & P030976 & 4.5 & 4 & 4 & 4 & 4 & 4 & 3 & 4 \\
\hline 2 & P031866 & 4.5 & 5 & 5 & 4 & 4 & 4 & 3 & 4 \\
\hline 3 & P032402 & 4 & 4 & 4 & 4 & 4 & 4 & 3 & 3 \\
\hline 4 & P038036 & 5 & 4 & 4 & 5 & 4 & 4 & 4 & 3 \\
\hline 5 & P040507 & 5 & 4 & 4 & 4 & 4 & 4 & 3 & 3 \\
\hline 6 & P043560 & 5 & 4 & 5 & 5 & 5 & 5 & 3 & 3 \\
\hline 7 & P044012 & 4 & 5 & 4 & 4 & 4 & 5 & 4 & 4 \\
\hline 8 & P044410 & 5 & 5 & 4 & 4 & 4 & 5 & 3 & 3 \\
\hline 9 & P044961 & 3.5 & 5 & 5 & 5 & 5 & 4 & 4 & 5 \\
\hline 10 & P045080 & 5 & 5 & 5 & 4 & 4 & 5 & 4 & 3 \\
\hline
\end{tabular}

\section{Perhitungan dan Pengelompokkan Core Factor dan Secondary Factor}

Setelah menentukan bobot nilai gap untuk kedua Aspek, yaitu Aspek Kinerja dan Sikap Kerja dengan cara yang sama, setiap aspek dikelompokkan menjadi 2 kelompok, yaitu kelompok Core Factor dan Secondary Factor. Dengan rumus sebagai berikut :

$$
\mathrm{NCF}=\frac{\sum N C(K N, S K)}{\sum \mathrm{IC}}
$$

Keterangan :

$\mathrm{NCF}$

: Nilai rata-rata core factor

$\mathrm{NC}(\mathrm{KN}, \mathrm{SK}) \quad$ : Jumlah total nilai core factor

IC

(Kinerja, Sikap Kerja)

: Jumlah item core factor

\section{$\mathrm{NSF}=\sum \mathrm{NS}(K N, S K)$ $\sum$ IS}

Keterangan :

\section{NSF}

$\mathrm{NS}(\mathrm{KN}, \mathrm{SK}) \quad$ : Jumlah total nilai secondary

factor

IS
(Kinerja, Sikap Kerja)

: Jumlah item secondary factor 
Tabel 7.

Core Factor dan Secondary Factor Aspek Kinerja

\begin{tabular}{|c|c|c|c|c|c|c|c|}
\hline \multirow{2}{*}{ No } & \multirow{2}{*}{ NIK } & \multicolumn{4}{|c|}{ Nilai Bobot Sub Aspek } & \multirow{2}{*}{ CF } & \multirow{2}{*}{ SF } \\
\cline { 3 - 6 } & & KN01 & KN02 & KN03 & KN04 & & \\
\hline 1 & P030976 & 4.5 & 4 & 3 & 4 & 3.5 & 4.25 \\
\hline 2 & P031866 & 4.5 & 4 & 3 & 4 & 3.5 & 4.25 \\
\hline 3 & P032402 & 4 & 4 & 3 & 3 & 3 & 4 \\
\hline 4 & P038036 & 5 & 4 & 4 & 3 & 3.5 & 4.5 \\
\hline 5 & P040507 & 5 & 4 & 3 & 3 & 3 & 4.5 \\
\hline 6 & P043560 & 5 & 5 & 3 & 3 & 3 & 5 \\
\hline 7 & P044012 & 4 & 5 & 4 & 4 & 4 & 4.5 \\
\hline 8 & P044410 & 5 & 5 & 3 & 3 & 3 & 5 \\
\hline 9 & P044961 & 3.5 & 4 & 4 & 5 & 4.5 & 3.75 \\
\hline 10 & P045080 & 5 & 5 & 4 & 3 & 3.5 & 5 \\
\hline
\end{tabular}

\section{Keterangan :}

Core Factor Aspek Kinerja $\quad$ : KN03 \& KN04

Secondary Factor Aspek Kinerja $\quad$ KN01 \& KN02

Tabel 8.

Core Factor dan Secondary Factor Aspek Sikap Kerja

\begin{tabular}{|c|c|c|c|c|c|c|c|}
\hline \multirow{2}{*}{ No } & \multirow{2}{*}{ NIK } & \multicolumn{4}{|c|}{ Nilai Bobot Sub Aspek } & \multirow{2}{*}{ CF } & \multirow{2}{*}{ SF } \\
\cline { 3 - 6 } & & SK01 & SK02 & SK03 & SK04 & & \\
\hline 1 & P038036 & 4 & 4 & 4 & 4 & 4 & 4 \\
\hline 2 & P031866 & 5 & 5 & 4 & 4 & 4 & 5 \\
\hline 3 & P030976 & 4 & 4 & 4 & 4 & 4 & 4 \\
\hline 4 & P032402 & 4 & 4 & 5 & 4 & 4.5 & 4 \\
\hline 5 & P040803 & 4 & 4 & 4 & 4 & 4 & 4 \\
\hline 6 & P037966 & 4 & 5 & 5 & 5 & 5 & 4.5 \\
\hline 7 & P038992 & 5 & 4 & 4 & 4 & 4 & 4.5 \\
\hline 8 & P039293 & 5 & 4 & 4 & 4 & 4 & 4.5 \\
\hline 9 & P041408 & 5 & 5 & 5 & 5 & 5 & 5 \\
\hline 10 & P043564 & 5 & 5 & 4 & 4 & 4 & 5 \\
\hline
\end{tabular}

\section{Keterangan :}

Core Factor Aspek Sikap Kerja : SK03 \& SK04

Secondary Factor Sikap Kerja : : SK01 \& SK02

\section{Perhitungan Nilai Total}

Dari hasil perhitungan core factor dan secondary factor dari setiap aspek, kemudian dilakukan perhitungan nilai total. Perhitungan bisa dilihat dengan rumus diberikut ini :

$(\mathrm{X}) \% . \mathrm{NCF}(\mathbf{k n}, \mathbf{s k})+(\mathrm{X}) \% \cdot \mathbf{N S F}(\mathbf{k n}, \mathbf{s k})=\mathbf{N}(\mathbf{k n}, \mathbf{s k})$

Keterangan :

NCF(kn,sk) : Nilai rata-rata Core Factor (Kinerja,

NSF(kn,sk) : Nilai rata-rata Secondary Factor (Kinerja, Sikap Kerja)

N(kn,sk) : Nilai total dari Aspek (Kinerja, Sikap

(X)\% : Nilai Persen yang diinputkan

Dari hasil wawancara penilaian promosi jabatan untuk menempati posisi jabatan Personal Banking Officer (PBO) harus sesuai dengan kriteria yang di tentukan maka nilai core factor dan secondary factor dari aspek kinerja dan aspek sikap kerja di tentukan dengan nilai $70 \%$ dan $30 \%$, seperti berikut :

Tabel 9. Nilai Total Aspek Kinerja

\begin{tabular}{|c|l|c|c|c|}
\hline No & \multicolumn{1}{|c|}{ NIK } & CF & SF & N(kn) \\
\hline 1 & P030976 & 3.5 & 4.25 & 3.8 \\
\hline 2 & P031866 & 3.5 & 4.25 & 3.8 \\
\hline 3 & P032402 & 3 & 4 & 3.4 \\
\hline 4 & P038036 & 3.5 & 4.5 & 3.9 \\
\hline 5 & P040507 & 3 & 4.5 & 3.6 \\
\hline 6 & P043560 & 3 & 5 & 3.8 \\
\hline 7 & P044012 & 4 & 4.5 & 4.2 \\
\hline 8 & P044410 & 3 & 5 & 3.8 \\
\hline 9 & P044961 & 4.5 & 3.75 & 4.2 \\
\hline 10 & P045080 & 3.5 & 5 & 4.1 \\
\hline
\end{tabular}

Tabel 10. Nilai Total Aspek Sikap Kerja 


\begin{tabular}{|c|l|c|c|c|}
\hline No & NIK & CF & SF & N(sk) \\
\hline 1 & P030976 & 4 & 4 & 4 \\
\hline 2 & P031866 & 4 & 5 & 4.4 \\
\hline 3 & P032402 & 4 & 4 & 4 \\
\hline 4 & P038036 & 4.5 & 4 & 4.3 \\
\hline 5 & P040507 & 4 & 4 & 4 \\
\hline 6 & P043560 & 5 & 4.5 & 4.8 \\
\hline 7 & P044012 & 4 & 4.5 & 4.2 \\
\hline 8 & P044410 & 4 & 4.5 & 4.2 \\
\hline 9 & P044961 & 5 & 5 & 5 \\
\hline 10 & P045080 & 4 & 5 & 4.4 \\
\hline & & & & \\
\hline
\end{tabular}

Tabel 11. Hasil Akhir Proses Profile Matching

\begin{tabular}{|c|c|c|c|c|c|}
\hline $\begin{array}{l}\mathbf{N} \\
\mathbf{0}\end{array}$ & NIK & $\begin{array}{c}\mathbf{N}(\mathbf{k n} \\
\quad)\end{array}$ & $\begin{array}{c}\text { N(sk } \\
\text { ) }\end{array}$ & Skor & $\begin{array}{c}\text { Rankin } \\
\text { g }\end{array}$ \\
\hline 1 & $\begin{array}{l}\text { P03097 } \\
6\end{array}$ & 3.8 & 4 & 3.88 & 8 \\
\hline 2 & $\begin{array}{l}\text { P03186 } \\
6\end{array}$ & 3.8 & 4.4 & 4.04 & 6 \\
\hline 3 & $\begin{array}{l}\mathrm{P} 03240 \\
2\end{array}$ & 3.4 & 4 & 3.64 & 10 \\
\hline 4 & $\begin{array}{l}\text { P03803 } \\
6\end{array}$ & 3.9 & 4.3 & 4.06 & 5 \\
\hline 5 & $\begin{array}{l}\text { P04050 } \\
7\end{array}$ & 3.6 & 4 & 3.76 & 9 \\
\hline 6 & $\begin{array}{l}\text { P04356 } \\
0\end{array}$ & 3.8 & 4.8 & 4.2 & 4 \\
\hline 7 & $\begin{array}{l}\text { P04401 } \\
2\end{array}$ & 4.2 & 4.2 & 4.2 & 3 \\
\hline 8 & $\begin{array}{l}\text { P04441 } \\
0\end{array}$ & 3.8 & 4.2 & 3.96 & 7 \\
\hline 9 & $\begin{array}{l}\text { P04496 } \\
1\end{array}$ & 4.2 & 5 & 4.52 & 1 \\
\hline 10 & $\begin{array}{l}\mathrm{P} 04508 \\
0\end{array}$ & 4.1 & 4.4 & 4.22 & 2 \\
\hline
\end{tabular}

Terjadi perubahan posisi ranking dari perhitungan sebelumnya, perubahan posisi ranking dapat dilihat pada tabel di bawah ini :

Tabel 12. Perbandingan Hasil Akhir

\section{Keterangan :}

$$
\text { Ranking }=(\mathbf{x}) \% . \mathrm{N}(\mathrm{kn})+(\mathrm{x}) \% . \mathrm{N}(\mathrm{sk})
$$

$\mathrm{N}(\mathrm{kn}) \quad$ : Nilai Total Kinerja

N(sk) : Nilai Total Sikap Kerja

$(\mathrm{x}) \% \quad$ : Nilai Persen yang diinputkan atau ditentukan

Berikut ini adalah perhitungan penentuan ranking : 


\begin{tabular}{|c|c|c|c|c|c|c|c|}
\hline \multicolumn{4}{|c|}{$\begin{array}{c}\text { Hasil Akhir Proses Profile } \\
\text { Hatching }\end{array}$} & \multicolumn{3}{c|}{ Hasil Akhir Proses Manual } \\
\hline No & NIK & Skor & Ranking & No & NK & Skor & Ranking \\
\hline 1 & P030976 & 3.88 & 8 & 1 & P030976 & 327.00 & 9 \\
\hline 2 & P031866 & 4.04 & 6 & 2 & P031866 & 347.00 & 6 \\
\hline 3 & P032402 & 3.64 & 10 & 3 & P032402 & 282.00 & 10 \\
\hline 4 & P038036 & 4.06 & 5 & 4 & P038036 & 370.00 & 4 \\
\hline 5 & P040507 & 3.76 & 9 & 5 & P040507 & 360.00 & 5 \\
\hline 6 & P043560 & 4.20 & 4 & 6 & P043560 & 380.00 & 3 \\
\hline 7 & P044012 & 4.20 & 3 & 7 & P044012 & 344.00 & 7 \\
\hline 8 & P044410 & 3.96 & 7 & 8 & P044410 & 331.00 & 8 \\
\hline 9 & P044961 & 4.52 & 1 & 9 & P044961 & 406.00 & 1 \\
\hline 10 & P045080 & 4.22 & 2 & 10 & P045080 & 383.00 & 2 \\
\hline
\end{tabular}

Setelah melakukan penilaian dengan metode profile matching pada sistem promosi jabatan dengan cara memilih kandidat dari costumer service officer (CSO) PT Bank Negara Indonesia (Persero), Tbk Kantor Cabang Utama Pecenongan untuk menempati posisi jabatan Personal Banking Officer (PBO) terlihat perbedaan nilai yang lebih baik dari perhitungan sebelumnya yang masih dilakukan dengan sederhana tanpa ada pemberian nilai target, pemetaan nilai bobot GAP dan nilai factor yakni Core Factor dan Secondary Factor yang dilanjutkan dengan hitung rangking.

\section{KESIMPULAN}

Berdasarkan pembahasan penentuan promosi jabatan dengan cara memilih kandidat dari costumer service officer (CSO) PT Bank Negara Indonesia (Persero), Tbk Kantor Cabang Utama Pecenongan untuk menempati posisi jabatan Personal Banking Officer (PBO) dengan menggunakan metode Profile Matching maka kesimpulan yang dapat diambil dari penelitian yang dilakukan oleh penulis adalah :

1. Hasil Hipotesa (H0) menyatakan bahwa tidak adanya perbedaan penilaian dalam promosi jabatan CSO untuk jabatan PBO antara sistem manual dengan menggunakan metode profile matching. Hasil penelitian menunjukan bahwa hipotesa penelitian (H0) ditolak artinya terdapat perbedaan hasil akhir penilaian dalam proses promosi jabatan di BNI KCU Pecenongan.

2. Hasil Hipotesa (H1) menyatakan bahwa adanya perbedaan penilaian dalam promosi jabatan CSO untuk jabatan PBO antara sistem manual dengan menggunakan metode profile matching. Dalam penelitian ini hipotesa $\mathrm{H} 1$ benar bahwa diperoleh perbedaan hasil yang signifikan dalam proses penilaian promosi jabatan sehingga dapat ditarik kesimpulan dengan menentukan terlebih dahulu aspek dan sub aspek penilaian, nilai target, GAP, pembobotan nilai GAP, mengkelompokan aspek menjadi 2 kelompok yaitu core factor dan secondary factor serta melakukan perhitungan nilai total dan nilai akhir sangat berpengaruh pada proses akhir dalam pemilihan kandidat yang berpeluang untuk naik jabatan, sehingga kandidat yang dihasilkan ideal atau cocok dengan jabatan yang di rekomendasikan karena sesuai dengan kompetensi dasar yang di miliki oleh karyawan.

3. Terjadi perubahan posisi rangking dari perhitungan sebelumnya yaitu :

1.) Karyawan dengan NIK P030976 sebelumnya berada pada posisi 9 setelah dilakukan perhitungan dengan profile matching dengan dukungan data yang lebih baik dan valid maka menjadi posisi 8

2.) Karyawan dengan NIK P038036 sebelumnya berada pada posisi 4 setelah dilakukan perhitungan dengan profile matching dengan dukungan data yang lebih baik dan valid maka menjadi posisi 5

3.) Karyawan dengan NIK P040507 sebelumnya berada pada posisi 5 setelah dilakukan perhitungan dengan profile matching dengan dukungan data yang lebih baik dan valid maka menjadi posisi 9

4.) Karyawan dengan NIK P043560 sebelumnya berada pada posisi 3 setelah dilakukan perhitungan dengan profile matching dengan dukungan data yang lebih baik dan valid maka menjadi posisi 4 
5.) Karyawan dengan NIK P044012 sebelumnya berada pada posisi 7 setelah dilakukan perhitungan dengan profile matching dengan dukungan data yang lebih baik dan valid maka menjadi posisi 3

6.) Karyawan dengan NIK P044410 sebelumnya berada pada posisi 8 setelah dilakukan perhitungan dengan profile matching dengan dukungan data yang lebih baik dan valid maka menjadi posisi 7

Dari hasil perankingan dengan Metode Profile Matching diambil 5 kandidat dari 10 CSO. Adapun 5 karyawan dengan rangking 5 besar adalah :

1.) Karyawan dengan NIK P044961

2.) Karyawan dengan NIK P045080

3.) Karyawan dengan NIK P044012

4.) Karyawan dengan NIK P043560

5.) Karyawan dengan NIK P038036

Dari hasil penelitian yang telah dilakukan oleh penulis, maka dapat diusulkan beberapa saran, diantaranya adalah :

1. Untuk sistem pendukung keputusan promosi jabatan ini dapat dikembangkan seiring perkembangan spesifikasi kebutuhan penggunaan sistem dan dapat di aplikasikan dengan metode lain untuk dapat membandingkan hasilnya.

2. Sebaiknya dalam proses penentuan promosi jabatan tidak lagi berdasarkan faktor tertentu saja seperti tingkat pendidikan, lamanya waktu bekerja, dan golongan, semua karyawan baiknya dapat di ikut sertakan sehingga semua karyawan semakin giat dalam bekerja agar dapat terpilih dalam promosi jabatan.

Sistem pendukung keputusan ini dapat dikembangkan bukan hanya dalam ruang lingkup promosi jabatan dari costumer service officer (CSO) PT Bank Negara Indonesia (Persero), Tbk Kantor Cabang Utama Pecenongan untuk menempati posisi jabatan Personal Banking Officer (PBO) tapi bisa juga digunakan untuk ruang lingkup lainnya sesuai kebutuhan.

\section{DAFTAR PUSTAKA}

Adhar, D. (2014). Sistem Pendukung Keputusan Pengangkatan Jabatan Karyawan pada PT . Ayn dengan Metode Profile Matching. Jatisi, $\mathrm{x}(\mathrm{x}), 16-29$.

Agustin, Y. H., Sulastri, S., Re, J., \& No, M. (2015). Kinerja Karyawan Untuk Kenaikan Jabatan Pada Pd Bpr Artha Sukapura Menggunakan Metode Profile Matching, 5(2), 67-78.

Ariwisanto Sianturi, F. (2015). Implementasi Sistem Pendukung Keputusan Kenaikan Jabatan Guru Dengan Model Profile Matching Pada Sekolah Sma Swasta Raksana Medan, 18(2).

Gautama, E. (2016). Penyetaraan Matakuliah Mahasiswa Transfer Menggunakan Metode Profile Matching dan Logika Fuzzy, 63-71.

Handayani, R. I. (2017). Berprestasi Dengan Metode Profile Matching Pada Pt . Sarana Inti Persada ( Sip ), 13(1), 28-34.

Hidayat, R. (2013). Vol . IX No . 2 September 2013 Pilar Nusa Mandiri Vol. IX No . 2 September 2013. Jurnal Pilar Nusa Mandiri, IX(2), 131-140.

Kristiana, T. (2015). Penerapan Profile Matching untuk Penilaian Kinerja Pegawai Negeri Sipil (PNS). Jurnal Pilar Nusa Mandiri, XI(2), 161-170.

Muqtadir, A., \& Purdianto, I. (2013). Sistem Pendukung Keputusan Kenaikan Jabatan Menggunakan Metode Profile Matching (Studi Kasus di PT. Industri Kemasan Semen Gresik). Teknik Informatika, Universitas PGRI Ronggolawe, 48-55.

Pratiwi, H. (2016). Sistem Pendukung Keputusan, 1171.

Purwanto, H. (2017). Penerapan Metode Profile Matching Dalam Sistem Pendukung Keputusan Penilaian Kinerja Karyawan Pada Pt. Hyundai Mobil Indonesia Cabang Kalimalang. Jurnal Techno Nusa Mandiri, 14(1), 15-20. Retrieved from http://ejournal.nusamandiri.ac.id/ejurnal/ind ex.php/techno/article/view/381 
Sugiyono. (2016). Metode Penelitian, 330.
Triandi, B. (2011). Jabatan Menggunakan Metode Profile, 1(2), 143-152. 